\title{
Effect of Different Drying Techniques on the Quality Attributes of Pineapple Powder
}

\author{
Sango Lule Victor ${ }^{1}$, Mukesh Kumar Garg ${ }^{2}$ and Kanika Pawar ${ }^{2 *}$ \\ ${ }^{1}$ Centre of Food Science and Technology, Chaudhary Charan Singh Haryana Agricultural \\ University, Hisar -125004 (Haryana), India \\ ${ }^{2}$ Department of Processing and Food Engineering, Chaudhary Charan Singh Haryana \\ Agricultural University, Hisar -125004 (Haryana), India \\ *Corresponding author
}

\section{Keywords}

Pineapple powder, Tray drying, Solar drying, Osmotic dehydration

Article Info

Accepted:

04 January 2019

Available Online:

10 February 2019

\section{A B S T R A C T}

The study was undertaken to compare the effect of tray and solar drying on the quality attributes of pineapple powder and its storability in different packaging materials. For the study, pineapple slices were first subjected to osmotic dehydration process using sugar syrup of $60{ }^{\circ}$ Brix for 12 hours at room temperature. Powder was prepared after solar (using natural solar cabinet dryer) and tray drying (at 50,60, 70 and $80{ }^{\circ} \mathrm{C}$ ) of pineapple slices. The pineapple powder was analyzed for physical (particle size, bulk density, color); chemical (moisture, protein, fat, carbohydrate, ascorbic acid); physico-chemical (water activity $\left(\mathrm{a}_{\mathrm{w}}\right)$, solubility, hygroscopicity), microbial and organoleptic evaluation. Pineapple powder prepared at tray drying temperature of $60{ }^{\circ} \mathrm{C}$ was of best quality among different temperatures range and hence was selected for storage studies. The particle size and colour changed significantly during storage period (6 months); however the changes in bulk density and water activity were insignificant. Solubility and hygroscopicity of the pineapple powder decreased significantly while the microbial load (total plate count, yeasts and moulds) increased significantly during storage. The proximate composition of the powder did not change significantly during storage period. The sensory attributes (colour, flavor, taste, texture and overall acceptability) decreased during storage but remained acceptable at the end of storage. Solar dried pineapple powder was found to be slightly better than tray dried pineapple powder especially in terms of sensory quality. Glass was found to be the best packaging material for storage of pineapple powder.

\section{Introduction}

Pineapple (Ananas comosus) belongs to the family Bromeliaceae. Pineapple is one of the most important commercial fruits in the world. Pineapple has an attractive flavour and a refreshing sugar-acid balance (Bartolome et al., 1995). It is a good choice fruit both for fresh consumption and processing. It is a good source of dietary fiber, vitamin A \& B and fairly rich in vitamin $\mathrm{C}$ and minerals like calcium, magnesium and iron. Pineapple is nature's healing fruit that has many health benefits (Joy and Abraham, 2013). Pineapple cultivation is confined to the areas of the high rainfall and humid coastal regions in the 
peninsular India and to the hilly areas of North Eastern region of the country. The most important and promising commercial varieties of pineapple in India are Kew and Queen. Pineapples can be processed into different products like juices, squash, wines, jams, concentrates and powder (Pineapple India, 2012).

During drying processes, water in food products is reduced to a level where the growth of spoilage microbes and chemical reactions are halted or slowed down. The reduced weight of dried foods and their longer shelf life stability reduce the costs and difficulties of product packaging, handling, storage and distribution (Barbosa-Canovas and Vega, 1996; Toledo, 1991). Pineapple powder is used as an ingredient in ice cream, beverages, confectionery, bakery and baby foods. The powder state provides a stable, natural and easily dosable ingredient which can be used in different foods and pharmaceutical products (Shrestha, 2007).

Osmotic dehydration of fruits is used as an intermediate step prior to conventional drying like tray or solar drying to reduce energy needs and improve quality. The selected drying method and adjustment of drying conditions can result in a product with good rehydration properties (Masters, 1976). Fresh and fully ripened fruits should be selected for drying.

The tray or cabinet dryer consists essentially of an insulated cabinet containing an air circulating fan moving the heated air through adjustable fables which is then forced horizontally between the food trays. Heat transfer is by conduction and convection (DiPersio et al., 2006). Solar drying produces better quality products compared to direct sun drying. Indirect solar dryers heat fresh air in a solar collector separate from the food chamber so that the food is not exposed to direct sunlight (Alvarez and Shene, 1994).
The high sugar and acid content of fruits make them safe to dry outdoors when conditions are favorable for drying.

Different packaging materials have different effects on storability of fruit powders. The advantages of glass include good barrier to water vapour and gas transmission, excellent clarity and durability plus chemical inertness. Plastic polymers are light weight and have superior functionality like flexibility. Several single particle characteristics are important to powder properties including particle size, shape, surface area, density, hardness and adsorption properties (Barbosa-Canovas et al., 2005). The properties of food in powder form have to be monitored to ensure the product quality, especially in order to keep the original nutritional feedstock characteristics and the product functional properties, such as solubility and hygroscopicity and the color (Pedro et al., 2010).

The benefit of new product development is the creation of food products with multiple purposes and improved shelf life plus reduction in postharvest losses hence increased farmers' income. Pineapple powder is an interesting product because of its long shelf life at ambient temperature, pleasant flavor, antioxidant activity, valuable source of bio-nutrients and multiple food applications. Drying is an important technique for fruit preservation but their effect on the quality and shelf life of pineapple powder has not yet been studied simultaneously. Thus the aim of this study was to compare the effect of tray and solar drying on the quality attributes of pineapple powder and to study the storability of pineapple powder in different packaging materials.

\section{Materials and Methods}

The present study was carried out to standardize the process for preparation of 
pineapple powder by tray drying and solar drying after osmotic dehydration. Pineapple powder was packed in glass, Low Density Polyethylene (LDPE) bags and aluminium laminated pouches for storage studies.

\section{Preparation of pineapple powder}

Good quality fully ripe pineapples were weighed, washed and peeled. The cores in the pineapples were removed by a corer. The pineapples were then sliced into slices of 3 $5 \mathrm{~mm}$ diameter and weighed. Osmotic dehydration was done using sugar syrup of $60^{\circ} \mathrm{B}$ overnight at room temperature. The pineapple slices were then removed from the sugar syrup rinsed with potable water and bloated. The slices were then weighed ready for drying. Some pineapple slices were tray dried directly without osmotic dehydration.

Tray drying (TD) was carried out at 50, 60, 70 and $80^{\circ} \mathrm{C}$. The weights of the slices were measured every one hour. The slices were broken into small pieces towards the end of drying to increase the drying rate. The pineapple pieces were left to cool and then ground into powder. Powder dried at $60^{\circ} \mathrm{C}$ after osmotic dehydration was of the best quality and was used for storage studies. Solar drying (SD) was done using a natural convection solar cabinet dryer for 3 days. Outside and inside temperatures were occasionally monitored with thermometer. The slices were then ground into powder for storage. Glass jars, LDPE bags and aluminium laminated pouches were used as packaging material for storage of pineapple powder.

Dehydration rate $(\mathrm{kg} / \mathrm{hr})=$

$\underline{\text { Initial Moisture content- Final moisture content }}$ Drying time

Dehydration ratio $=\underline{\text { Initial moisture content }}$ Final moisture content

Yield $(\%)=$ Weight of powder $\times 100$

Weight of fresh pineapple
The particle sieve analysis was done by a typical sieve analysis method using a nested column of sieves (ranging from 250 - 2000 $\mu \mathrm{m})$. The sample was poured onto the top sieve (which had the widest openings) and the column was typically placed in a mechanical shaker. The shaker shook the column for about five minutes after which the material on each sieve was weighed and divided by the total weight to give a percentage retained on each sieve (Barbosa-Canovas et al., 2005).

Bulk density of the pineapple powder was measured by filling the powder of a known mass $(\mathrm{m})$ in a measuring cylinder and noting the volume (v) occupied by the powder (Barbosa-Canovas et al., 2005). Bulk density $=(\mathrm{m} / \mathrm{v})$.

Moisture content was estimated in the samples using A.O.A.C. method (1999). Five $\mathrm{g}$ of sample was weighed and transferred to pre-dried dish. Weighed sample was dried in hot air oven at $105^{\circ} \mathrm{C}$. The dish with dried sample was transferred to desiccators, cooled to room temperature and weighed. Crude fiber was estimated using standard method of A.O.A.C. (1999). The method involves acid and alkali hydrolysis along with ashing.

The ascorbic acid determination was performed by the titrimetric method based on the reduction of the indicator 2, 6dichlorophenolindophenol by the ascorbic acid as described in A.O.A.C. (1999). The water activity of pineapple powder was measured by a "Novasina" water activity instrument, model TH2/RTD33 (made by Novasina AG, Lachen, Switzerland).

Solubility was determined as recommended by Cano-Chauca et al., (2005). $100 \mathrm{ml}$ of water and $1 \mathrm{~g}$ of pineapple fruit powder were homogenized in a blender for 5 minutes. The solution was then centrifuged at $3000 \mathrm{x} \mathrm{g}$ for $5 \mathrm{~min}$. An aliquot of $25 \mathrm{ml}$ of the supernatant 
was transferred to a petri dish and dried in an oven at $90^{\circ} \mathrm{C}$ for $6 \mathrm{hr}$. The solubility (\%) was calculated based on the dry weight of the supernatant.

Hygroscopicity was measured according to the method described by Cano-Chauca et al., (2005), with modifications. At least $2 \mathrm{~g}$ of powder was placed in a dessicator containing saturated ammonium chloride solution with relative humidity of $79.5 \%$. After one week, the moisture gained by the powder was measured.

Pineapple powder was analyzed to enumerate the total plate count plus yeasts and moulds using serial dilution technique and spread plate method (all the manipulations were done in laminar flow chamber using sterile glassware). One gram of fine powder was dissolved in nine $\mathrm{ml}$ of sterilized water and serial dilution done. $100 \mu \mathrm{ml}$ of appropriate dilution was spread on sterilized petri plates with media. The plate count and potato dextrose agar for Total Plate Count and Yeast and Mould respectively were used. After spreading, the plates were inverted and incubated at $28 \pm 1^{\circ} \mathrm{C}$ for 48 hours for growth. After incubation period the colonies were counted using the colony counter.

\section{Organoleptic evaluation}

The pineapple powder was subjected to sensory evaluation soon after preparation and at $15,30,45,60,75,90,105$ and $120^{\text {th }}$ day of storage by a semi-trained panel following the 6-point hedonic rating scale as per the methods described by Ranganna (2003). The overall acceptability of the products was based on the mean scores obtained from all the sensory characters.

\section{Statistical analysis}

The data obtained in the present investigation was subjected to analysis of variance
(ANOVA) technique and analyzed according to two factorial completely randomized design (CRD). The critical difference value at 5 per cent level was used for making comparisons among different treatments during the storage period.

\section{Results and Discussion}

\section{Physico-chemical composition of fresh pineapple fruits}

The composition of the pineapple fruits varies from variety to variety and it is also dependent on the different agro-climatic conditions in which fruits are grown plus storage conditions. The pineapple fruits were analyzed for different physical and chemical characteristics and data shows that the pineapple fruits had an average fruit weight of $2.56 \mathrm{~kg}$ which consisted of $50 \%$ flesh, $20 \%$ crown, $25 \%$ peel and $5 \%$ core.

The pineapple fruit had moisture content, total soluble solids (TSS), pH, acidity and ascorbic acid of $86.28 \%, 8.67^{\circ} \mathrm{B}, 3.47,0.63 \%$ and $29.67 \mathrm{mg} / 100 \mathrm{~g}$ respectively as shown in Table 1. The pineapple slices recovery was $50 \%$ from the whole fruit. The pineapple powder recovery for tray and solar drying were 7.6 and $8.5 \%$ respectively (Table 1). Karim (2005) reported that fresh pineapple had $\mathrm{pH} 3.52$, TSS $11.89{ }^{\circ} \mathrm{B}$, acidity $1.15 \%$ (citric acid), moisture content $81.31 \%$, ascorbic acid $31.6 \mathrm{mg} / 100 \mathrm{~g}$ and firmness of 3.16 kgf. Hemalatha and Anbuselvi (2013) reported fresh pineapple had composition of $87.3 \%$ moisture content, $1.8 \%$ ash, $2.03 \%$ acidity, $21.5 \mathrm{mg} / 100 \mathrm{~g}$ ascorbic acid, $13.3{ }^{\circ} \mathrm{B}$ TSS, $0.41 \%$ crude fiber and $7.2 \mathrm{mg} / 100 \mathrm{~g}$ protein.

These variations observed by various workers could be due to the difference in environmental conditions, fruit maturity, storage conditions and analytical procedures. 


\section{Drying experiments}

\section{Tray drying (TD)}

The drying time for the osmotically treated pineapple slices were lower than for the slices dried directly without osmotic dehydration. During drying, the osmotically dehydrated slices became crumpled hence losing the flat circular shape. It was therefore needed to break the slices into small pieces in order to increase drying rate. The slices which did not undergo osmotic dehydration had higher moisture content at the end of drying period and did not lose any extra moisture even with increased drying time. $\mathrm{P}_{1} 50$ (pineapple samples dried at $50{ }^{\circ} \mathrm{C}$ without osmotic dehydration) had the highest drying time of 11.5 hours while $\mathrm{P}_{2} 80$ (pineapple samples dried at $80{ }^{\circ} \mathrm{C}$ after osmotic dehydration) had the least drying time of 6.8 hours (Table 2). The drying rates also depended on the initial weights of pineapple slices put in tray dryer which varied for the different drying temperatures.

\section{Solar drying (SD)}

Solar drying of pineapple slices was carried out after osmotic dehydration at $60{ }^{\circ} \mathrm{B}$. The drying time was 3 days. The day temperature range was 30 to $45{ }^{\circ} \mathrm{C}$. The initial moisture content $(\%)$ of the slices was $57.32 \pm 0.01$ and the final moisture content (\%) was $4.26 \pm 0.02$ and $\%$ yield of powder was $8.5 \%$. Towards the end of drying, the pineapple slices were broken into small pieces to create flat surface and hence increase the drying rate after they had wrinkled due to osmotic dehydration.

\section{Changes in pineapple powder during storage}

After preparation, the tray dried (TD) and solar dried (SD) pineapple powder was packed in Glass bottles, LDPE bags and
Aluminium laminated pouches (ALP) and stored at room temperature for a period of 120 days. Analysis was done fortnightly. The analysis was done for physical and chemical parameters. Microbial analysis and organoleptic evaluation of the powder were also carried out. The results are presented below.

Changes in physical, chemical and physicochemical quality of pineapple powder during storage

The pineapple powder was stored for 120 days, during which the effect of the different drying methods and packaging materials on the quality attribute of pineapple powder was studied.

\section{Particle size $(\mu \mathrm{m})$ and Bulk density $(\mathrm{g} / \mathrm{cc})$}

The particle size of tray and solar dried pineapple powder stored in different packaging materials are presented in Table 3 . The particle size of tray dried pineapple powder was $261 \mu \mathrm{m}$ at 0 -day while for solar dried pineapple powder it was $265 \mu \mathrm{m}$. It was observed that the particle size of the pineapple powder progressively and significantly increased during storage. There was significant difference among the treatments with solar dried powder stored in LDPE bags having the highest increase up to $355 \mu \mathrm{m}$ at 120 days of storage. The bulk density of tray and solar dried pineapple powder stored in different packaging materials is presented in Table 4. At 0-day, solar dried pineapple powder had bulk density of $0.681 \mathrm{~g} / \mathrm{cc}$ while tray dried pineapple powder had bulk density of $0.669 \mathrm{~g} / \mathrm{cc}$. There was no significant difference among the different treatments. There was no significant change in the bulk density of the pineapple powder during storage. The interactions between the treatments and the storage were also nonsignificant. 
The particle size and bulk density of pineapple powder increased during storage (Tables 3 and 4). The increase in particle size during storage and the difference among treatments was significant.

The change in bulk density during storage was non-significant. Particle size is the most important physical quality parameter of pineapple powder as it affects all other powder properties including bulk density plus flowability. The pineapple powder produced remained within the moderately fine range $(180-355 \mu \mathrm{m})$. The bulk density of powders is related to moisture content plus structure and size of the particles. Moisture gain by the hygroscopic powder during storage explains the increase in particle size and bulk density. Caking and agglomeration of powder particles occurred during storage. The difference in moisture content among the treatments explains their particle size difference. Moisture content gain though non-significant was also affected by the permeability of the different packaging. Chegini and Ghobadian (2005) reported that the higher drying temperature resulted in lower bulk density during spray drying of powder.

\section{Moisture content (\%)}

The moisture content (\%) of tray and solar dried pineapple powder stored in different packaging materials is presented in Table 5. At 0-day, tray dried pineapple powder had moisture content of $3.85 \%$ while solar dried pineapple powder had moisture content of $4.14 \%$. There was no significant difference among the different treatments. There was no significant change in the moisture content of the pineapple powder during storage. The interactions between the treatments and the storage were also non-significant.

At $0^{\text {th }}$ day, tray dried pineapple powder had moisture content of $3.85 \%$ while solar dried pineapple powder had moisture content of $4.14 \%$. There was no significant difference among the treatments in terms of moisture content. The change in moisture content of the pineapple powder during the storage period was non-significant (Table 5). Zakaria (2005) reported pineapple core powder had $4.8 \%$ moisture content. While moisture content of $2.65 \%$ was found by Suhaimi (2010) in spray dried pineapple powder.

\section{Fiber content $(\%)$}

The fiber content $(\%)$ of tray and solar dried pineapple powder stored in different packaging materials is presented in Table 6 . At 0-day, the fiber content of tray dried pineapple powder was $6.07 \%$ while that of solar dried pineapple was $6.13 \%$. There was no significant difference among the different pineapple powder treatments. There was no significant change in the fiber content of the pineapple powder during storage. The interactions between the treatments and the storage were also non-significant.

At $0^{\text {th }}$ day, the fiber content of tray dried pineapple powder was $6.07 \%$ while that of solar dried pineapple was $6.13 \%$. There was no significant difference among the different pineapple powder treatments. There was no significant change in the fiber content of the pineapple powder during storage (Table 6). DiPersio et al., (2006) reported that calorie and fiber content of dried fruits does not change during storage. Caking reduces the bio-availability and digestibility of nutrients. This can explain the slight decrease in some of nutrients. During storage, some nutrients also form complexes with other constituents present in the powder hence becoming unavailable. Zakaria (2005) reported a fiber content of $9.72 \%$ in pineapple core powder while $1.72 \%$ fiber was found out by Suhaimi (2010) in spray dried pineapple powder. 


\section{Ascorbic acid (mg/100g)}

The ascorbic acid (mg/100g) of tray and solar dried pineapple powder stored in different packaging materials is presented in Table 7 . The ascorbic acid content of tray dried and solar dried pineapple powder were 10.23 and $11.37 \mathrm{mg} / 100 \mathrm{~g}$ respectively at 0 -day. There was significant difference among the different treatments with solar dried pineapple powder having slightly higher ascorbic acid content. There was progressive and significant decrease in the ascorbic acid content of the pineapple powder during storage. Pineapple powder stored in glass better retained ascorbic acid during storage compared to other packaging materials. The interactions between the treatments and the storage were also significant.

The ascorbic acid content of tray dried and solar dried pineapple powder were 10.23 and $11.37 \mathrm{mg} / 100 \mathrm{~g}$ respectively at 0 -day. There was significant decrease in ascorbic acid content of the pineapple powder during storage (Table 7). There was slight difference in ascorbic acid content among the treatments. The decrease in ascorbic acid is also related to the type of packaging used which did not completely prevent the access of moisture and oxygen, contributed to the substantial deterioration in the levels of ascorbic acid through oxidation. Glass having the best impermeability had the highest retention of ascorbic acid. Sharma et al., (2003) reported a decrease in ascorbic acid content and total sugar of apple powder stored in polyethylene and laminated pouches over a period of 6 months.

\section{Water activity}

The water activity of tray and solar dried pineapple powder stored in different packaging materials is presented in Table 8 . At 0-day, tray dried pineapple powder had water activity of 0.342 while solar dried pineapple powder had water activity of 0.355 . There was no significant difference among the different treatments. During storage there was no significant change in the water activity. The interactions between the treatments and the storage were also nonsignificant.

The change in water activity of pineapple powder during storage was non-significant (Table 8). The difference in treatments was also non-significant. The water activity was within the range of 0.34 to 0.45 during storage (Table 8) whereas an increase can be justified due to the increase in the moisture content of pineapple fruit powder. These conditions are considered safe since in the low water activity conditions, pathogenic bacteria cannot grow. The increase in water activity is also related to the permeability of the packaging materials and the storage conditions. Pedro et al (2010) observed values for the passion fruit powder with different concentrations of maltodextrin, ranging from 0.18 to 0.20 and verified that there is a change in water activity with the concentration of maltodextrin.

\section{Solubility (\%)}

The solubility (\%) of tray and solar dried pineapple powder stored in different packaging materials is presented in Table 9 . At $0^{\text {th }}$ day, tray dried pineapple powder had solubility of $94.1 \%$ while solar dried pineapple powder had solubility of $95.1 \%$. There was significant difference among the different treatments. There was significant change in the solubility of the pineapple powder during storage. At the end of storage, solar dried pineapple powder stored in glass bottles had solubility of $88.9 \%$ while pineapple powder stored in LDPE bags had the lowest solubility of $82.5 \%$. The interactions between the treatments and the storage were significant. 
The mean values for solubility of pineapple powder decreased significantly during storage from 94.6 to $86.4 \%$ (Table 9). Solubility is one of the most utilized parameters to verify the capacity of a powder to remain in a homogenous mixture with water. The decrease in solubility during storage was due to caking and browning. Caking causes agglomeration and hardening of particles which dissolve less in water. Powder becomes tough and more energy is required to dissolve it. Juliana et al., (2013) reported a decrease in the mean values of solubility of passion fruit powder until the last day of storage with variation from 81.60 to $75.79 \%$. This could be attributed to sugar crystallization that occurred due to the relative humidity and the storage temperature.

\section{Hygroscopicity (\%)}

The hygroscopicity (\%) of tray and solar dried pineapple powder stored in different packaging materials is presented in Table 10 . At 0-day, tray dried pineapple powder had hygroscopicity of $20.92 \%$ while solar dried pineapple powder had hygroscopicity of $19.13 \%$. There was significant difference among the different treatments. There was significant change in the hygroscopicity of the pineapple powder during storage. The interactions between the treatments and the storage were also significant.

The mean values of hygroscopicity decreased from $20.03 \%$ at 0 days to $19.08 \%$ at 120 days (Table 10). The slightly higher hygroscopicity of the tray dried pineapple powder can be explained by the fact that a drier powder has a higher water concentration gradient with the atmosphere. Hence the drier powder has more capacity to absorb moisture from the atmosphere. Presence of sugar in the powder which is due to osmotic dehydration also contributed to the hygroscopicity. Juliana et al., (2013) reported hygroscopicity of $22.71 \mathrm{~g}$ of absorbed water/100 g) in passion fruit powder.

\section{Changes in microbial quality of pineapple powder during storage}

The pineapple powder stored in different packaging materials was analyzed for total plate count plus yeasts and molds. The results of the microbial enumeration are presented below.

\section{Total plate count (CFU/g)}

The total plate count (CFU/g) of tray and solar dried pineapple powder stored in different packaging materials is presented in Table 11. The total plate count of tray dried and solar dried pineapple powder were 33 and $50 \mathrm{CFU} / \mathrm{g}$ respectively at 0-day. There was significant difference among the different treatments with solar dried pineapple powder having a higher total plate count. There was progressive and significant increase in the total plate count of the pineapple powder during storage. Pineapple powder stored in glass had the lowest total plate count while pineapple powder stored in LDPE had the highest total plate count at 120 days. The interactions between the treatments and the storage were also significant.

\section{Yeast and mold count (CFU/g)}

The yeast and mold count (CFU/g) of tray and solar dried pineapple powder stored in different packaging materials is presented in Table 12. Yeast and molds were first detected at 45 days of storage in LDPE pineapple powder with a count of $3 \mathrm{CFU} / \mathrm{g}$. Afterwards, there was progressive and significant increase in the yeast and mold count of the pineapple powder during storage. Pineapple powder stored in glass had yeast and mold count of 20 $\mathrm{CFU} / \mathrm{g}$ while pineapple powder stored in LDPE had yeast and mold count of $27 \mathrm{CFU} / \mathrm{g}$ 
count at 120 days. The interactions between the treatments and the storage were nonsignificant.

The pineapple powder was analyzed for both total plate count plus yeast and mold count. It was observed that the microbial count increased with storage period in all the treatments (Tables 11 and 12). At $0^{\text {th }}$ day, solar dried pineapple powder had higher total plate count than tray dried powder.

The microbial counts were indicating that the pineapple was still safe for use even by 120 days of storage at room temperature. Pineapple powder stored in LDPE bags had the highest increase in microbial count while pineapple powder stored in glass had the lowest increase. The rate of increase in microbial count during storage is influenced by moisture content, storage temperatures, sugar and acidity levels. The high acidity and sugar levels might have ensured a slower rate of increase in the microbial count up to 120 day storage period.

Osmotic dehydration increased the sugar content of the pineapple powder and also helped in controlling microbial growth by reducing the water activity. Pineapple products are high acid foods which are spoiled by moulds and yeasts. The pineapple powder had low moisture content and water activity hence reduced microbial growth. Microbial load of the powder could also have been increased due to handling practices during analysis.

The microbial load was below the maximum allowance of $1000 \mathrm{CFU} / \mathrm{g}$ and $100 \mathrm{CFU} / \mathrm{g}$ for total plate count and yeast plus mold count respectively at the end of storage. Satisfactory microbiological results of fruit powder were also reported by Juliana et al., (2013) and Dattatreya et al., (2012).
Changes in sensory quality scores of pineapple powder during storage

The color, flavor, taste, texture and overall acceptability scores of tray and solar dried pineapple powder stored in different packaging materials are presented in Tables $13-17$.

The color scores of the pineapple powder for the first 30 days of storage were 6 . At 45 days of storage, the color scores of the pineapple powder started to decrease significantly until the end of storage. It was observed that the color scores of pineapple powder were significantly different after 30 days. Solar dried pineapple powder stored in glass had the highest color score of 5.7 at 120 days while tray dried pineapple powder stored in aluminium laminated pouches had the lowest color score of 4 . The interactions between treatments and storage periods were significant.

The flavor scores of the pineapple powder for the first 15 days of storage were 6 . At 30 days of storage, the flavor scores of the pineapple powder started to decrease significantly until the end of storage. It was observed that the flavor scores of pineapple powder were significantly different after 30 days. Solar dried pineapple powder stored in glass had the highest flavor score of 5.5 at 120 days while tray dried pineapple powder store in LDPE bags had the lowest flavor score of 4 . The interactions between treatments and storage periods were non-significant.

The taste scores of the pineapple powder for the first 15 days of storage were 6 . At 30 days of storage, the taste scores of the pineapple powder started to decrease significantly until the end of storage. It was observed that the taste scores of pineapple powder were significantly different after 15 days. Solar dried pineapple powder stored in glass had the 
highest taste score of 5.5 at 120 days while tray dried pineapple powder stored in LDPE bags had the lowest color score of 4 . The interactions between treatments and storage periods were non significant.

Tray and solar dried pineapple powder had texture scores of 5.7 and 6.0 respectively at 0 day. The difference among treatments was significant at 0.19 . There was significant decrease in texture scores during storage. Solar dried pineapple powder stored in glass had the highest texture score of 5.2 at 120 days. The interactions between treatments and storage periods were non-significant.

The overall acceptability scores of tray and solar dried pineapple powder stored in different packaging materials are presented in Table 17. Tray and solar dried pineapple powder had scores of 5.9 and 6 respectively at 0 -days. There was significant difference in overall acceptability among the treatments. Solar dried pineapple powder stored in glass had the highest score of 5.5 at 120 days while tray dried pineapple powder stored in LDPE bags had the lowest score of 4.1. There was significant change in overall acceptability of pineapple powder during storage but remained above 4 which are like moderately. The interactions between treatments and storage periods were significant

The color, flavor, taste and texture scores of the pineapple powder decreased during storage (Tables 13-17). Significant differences in sensory quality scores were observed among the different treatments. The presence of sugar in the pineapple powder as a result of osmotic dehydration significantly impacted consumer acceptance. Solar dried pineapple powder was slightly better than tray dried pineapple powder. Glass was the best material for packaging of pineapple powder. The overall acceptability of the pineapple powder decreased during storage but remained acceptable at 120-days. Solar dried pineapple powder stored in glass had the highest overall acceptability. Tray dried pineapple powder stored in LDPE bags had the lowest overall acceptability. All sensory scores of the pineapple powder were at least 4.0 which is like moderately at 120-days.

Greater stability and quality of pineapple powder was achieved by maintaining fresh or optimum conditions of the raw materials. The better sensory quality of solar dried pineapple powder can be explained by the fact that drying was done at lower temperature for a longer period of time after osmotic dehydration. Solar drying was also carried out within the optimum temperature range which is 35 to $45{ }^{\circ} \mathrm{C}$. The quality of solar dried products differs from area to area. Tray drying was done at $60{ }^{\circ} \mathrm{C}$ which is optimum. Osmotic dehydration helps in minimizing heat damage to food tissue, colour, flavor and less discolouration of fruits by browning. Increase in drying temperature leads to increase in rate of undesirable reactions like browning and texture changes. Sensory scores of the pineapple powder including color, flavor and texture were affected by caking or agglomeration. Dark storage conditions were ideal to prevent colour loss. The light transmittance of glass and LDPE bags was minimized by storage in an opaque secondary packaging.

Caking leads to increase in particle size of the pineapple powder and also off flavors. Agglomeration of particles occurs as a result of moisture gain by the pineapple powder which is hygroscopic.

The particles become tougher hence affecting texture and taste. Glass by the nature of its chemical inertness had no chemical impact on the pineapple powder unlike LDPE bags and aluminium laminated pouches. 
Colour and flavor of the pineapple powder is also affected by browning and oxidation reactions. The decrease in lightness of the powder during storage was an indication of browning taking place. Browning reactions change the colour, decrease nutritional value and solubility, create off flavours and induce texture changes. Browning pigments give off flavours which affect the taste. The rate of non-enzymatic browning depends on parameters such as water activity, temperature, $\mathrm{pH}$ and nutritional composition. Similar results were reported by Swain et al., (2013) and Sharma et al., (2003). Konopacka et al., (2009) reported that with the exception of basic fruit taste, the sensory attributes investigated of fruits were significantly influenced by the osmotic agent used for impregnation before fruit drying.

Table.1 Physical and chemical characteristics of pineapple fruits

\begin{tabular}{|l|l|}
\hline Parameter & Mean \pm SD \\
\hline Fruit weight $(\mathbf{k g})$ & $2.56 \pm 0.01$ \\
\hline Moisture content $(\% \mathbf{~ w b )}$ & $86.28 \pm 0.02$ \\
\hline Total Soluble Solids ( $\mathbf{0}$ ) & $8.67 \pm 0.47$ \\
\hline pH & $3.47 \pm 0.01$ \\
\hline Acidity (\%) & $0.63 \pm 0.01$ \\
\hline Firmness (kg) & $3.93 \pm 0.09$ \\
\hline Ascorbic acid (mg/100g) & $29.67 \pm 0.47$ \\
\hline
\end{tabular}

Table.2 Moisture content and drying characteristics of pineapple slices (Tray drying)

\begin{tabular}{|c|c|c|c|c|c|}
\hline $\begin{array}{l}\text { Sample } \\
\text { code }\end{array}$ & $\begin{array}{l}\text { Initial } \\
\text { moisture } \\
\text { content } \\
(\%)\end{array}$ & $\begin{array}{l}\text { Final } \\
\text { moisture } \\
\text { content } \\
(\%)\end{array}$ & $\begin{array}{l}\text { Drying } \\
\text { time } \\
\text { (hours) }\end{array}$ & $\begin{array}{l}\text { Drying } \\
\text { rate } \\
(\mathrm{kg} / \mathrm{h})\end{array}$ & $\begin{array}{l}\text { Dehydration } \\
\text { ratio }\end{array}$ \\
\hline$P_{1} 50$ & 85.5 & 10.2 & 11.5 & 0.122 & 8.38 \\
\hline$P_{2} 50$ & 56.6 & 4.5 & 9.6 & 0.130 & 12.5 \\
\hline$P_{1} 60$ & 86.4 & 9.4 & 10 & 0.142 & 9.19 \\
\hline $\mathbf{P}_{2} 60$ & 56.8 & 3.9 & 8.0 & 0.147 & 14.56 \\
\hline$P_{1} 70$ & 86.2 & 8.4 & 9.0 & 0.138 & 10.26 \\
\hline $\mathbf{P}_{\mathbf{2}} \mathbf{7 0}$ & 55.9 & 3.8 & 7.4 & 0.143 & 14.71 \\
\hline $\mathbf{P}_{1} 80$ & 85.4 & 7.8 & 8.0 & 0.141 & 10.95 \\
\hline $\mathbf{P}_{\mathbf{2}} \mathbf{8 0}$ & 55.7 & 3.3 & 6.8 & 0.124 & 16.88 \\
\hline
\end{tabular}

KEY

1. $\mathrm{P}_{1} 50, \mathrm{P}_{1} 60, \mathrm{P}_{1} 70$ and $\mathrm{P}_{1} 80$ are pineapple samples dried at $50,60,70$ and $80{ }^{\circ} \mathrm{C}$ respectively without osmotic dehydration.

2. $\mathrm{P}_{2} 50, \mathrm{P}_{2} 60, \mathrm{P}_{2} 70$ and $\mathrm{P}_{2} 80$ are pineapple samples dried at $50,60,70$ and $80{ }^{\circ} \mathrm{C}$ respectively after osmotic dehydration 
Table.3 Effect of different treatments on the particle size $(\mu \mathrm{m})$ of pineapple powder during storage

\begin{tabular}{|c|c|c|c|c|c|c|c|c|c|c|}
\hline \multirow[t]{2}{*}{ Treatments } & \multicolumn{10}{|c|}{ Period of storage (days) } \\
\hline & $\mathbf{0}$ & 15 & 30 & 45 & 60 & 75 & 90 & 105 & 120 & Mean \\
\hline GLASS TD & 261 & 262 & 273 & 281 & 296 & 315 & 318 & 319 & 321 & 294 \\
\hline GLASS SD & 265 & 268 & 274 & 284 & 298 & 317 & 319 & 321 & 325 & 297 \\
\hline LDPE TD & 261 & 263 & 273 & 285 & 307 & 318 & 323 & 328 & 336 & 299 \\
\hline LDPE SD & 265 & 273 & 296 & 316 & 327 & 337 & 342 & 347 & 355 & 318 \\
\hline ALP TD & 261 & 263 & 278 & 288 & 303 & 318 & 319 & 321 & 326 & 297 \\
\hline ALP SD & 265 & 270 & 283 & 292 & 310 & 320 & 322 & 324 & 332 & 302 \\
\hline Mean & 263 & 267 & 280 & 291 & 307 & 321 & 324 & 327 & 333 & \\
\hline
\end{tabular}

Table.4 Effect of different treatments on the bulk density $(\mathrm{g} / \mathrm{cc})$ of pineapple powder during storage

\begin{tabular}{|c|c|c|c|c|c|c|c|c|c|c|}
\hline \multirow[t]{2}{*}{ Treatments } & \multicolumn{10}{|c|}{ Period of storage (days) } \\
\hline & $\mathbf{0}$ & 15 & 30 & 45 & 60 & 75 & 90 & 105 & 120 & Mean \\
\hline GLASS TD & 0.669 & 0.674 & 0.683 & 0.687 & 0.688 & 0.691 & 0.691 & 0.694 & 0.696 & 0.686 \\
\hline GLASS SD & 0.681 & 0.685 & 0.686 & 0.69 & 0.693 & 0.695 & 0.698 & 0.698 & 0.699 & 0.692 \\
\hline LDPE TD & 0.669 & 0.68 & 0.685 & 0.688 & 0.69 & 0.693 & 0.695 & 0.7 & 0.711 & 0.69 \\
\hline LDPE SD & 0.681 & 0.685 & 0.689 & 0.691 & 0.693 & 0.694 & 0.697 & 0.703 & 0.712 & 0.694 \\
\hline ALP TD & 0.669 & 0.671 & 0.688 & 0.691 & 0.691 & 0.692 & 0.693 & 0.695 & 0.703 & 0.688 \\
\hline ALP SD & 0.681 & 0.684 & 0.689 & 0.693 & 0.695 & 0.696 & 0.696 & 0.698 & 0.7 & 0.692 \\
\hline Mean & 0.675 & 0.68 & 0.687 & 0.69 & 0.692 & 0.693 & 0.695 & 0.698 & 0.703 & \\
\hline \multicolumn{11}{|c|}{ CD at $5 \%$ Treatment $(T)=$ N.S Storage $(S)=$ N.S TxS $=$ N.S } \\
\hline \multicolumn{3}{|c|}{ N.S = Non-significant } & & & & & & & & \\
\hline
\end{tabular}

Table.5 Effect of different treatments on the moisture content (\%) of pineapple powder during storage

\begin{tabular}{|c|c|c|c|c|c|c|c|c|c|c|}
\hline \multirow[t]{2}{*}{ Treatments } & \multicolumn{10}{|c|}{ Period of storage (days) } \\
\hline & 0 & 15 & 30 & 45 & 60 & 75 & 90 & 105 & 120 & Mean \\
\hline GLASS TD & 3.85 & 3.91 & 4.01 & 4.09 & 4.15 & 4.19 & 4.24 & 4.25 & 4.29 & 4.11 \\
\hline GLASS SD & 4.14 & 4.16 & 4.21 & 4.22 & 4.26 & 4.33 & 4.39 & 4.43 & 4.44 & 4.29 \\
\hline LDPE TD & 3.85 & 4.21 & 4.60 & 4.71 & 4.75 & 4.82 & 4.93 & 5.01 & 5.12 & 4.67 \\
\hline LDPE SD & 4.14 & 4.36 & 4.61 & 4.78 & 4.79 & 4.83 & 4.94 & 5.06 & 5.15 & 4.74 \\
\hline ALP TD & 3.85 & 4.11 & 4.31 & 4.50 & 4.55 & 4.61 & 4.64 & 4.68 & 4.71 & 4.44 \\
\hline ALP SD & 4.15 & 4.16 & 4.25 & 4.35 & 4.56 & 4.61 & 4.65 & 4.71 & 4.76 & 4.47 \\
\hline Mean & 3.99 & 4.15 & 4.33 & 4.44 & 4.51 & 4.57 & 4.63 & 4.69 & 4.74 & \\
\hline \multicolumn{11}{|c|}{ CD at $5 \%$ Treatment $(T)=$ N.S Storage $(S)=$ N.S TxS $=$ N.S } \\
\hline \multicolumn{3}{|c|}{ N.S = Non-significant } & & & & & & & & \\
\hline
\end{tabular}


Int.J.Curr.Microbiol.App.Sci (2019) 8(2): 324-341

Table.6 Effect of different treatments on the fiber content (\%) of pineapple powder during storage

\begin{tabular}{|c|c|c|c|c|c|c|c|c|c|c|}
\hline \multirow[t]{2}{*}{ Treatments } & \multicolumn{10}{|c|}{ Period of storage (days) } \\
\hline & $\mathbf{0}$ & 15 & 30 & 45 & 60 & 75 & 90 & 105 & 120 & Mean \\
\hline GLASS TD & 6.07 & 6.03 & 5.99 & 5.97 & 5.96 & 5.96 & 5.94 & 5.94 & 5.93 & 5.98 \\
\hline GLASS SD & 6.13 & 6.10 & 6.07 & 5.99 & 5.97 & 5.96 & 5.94 & 5.93 & 5.92 & 6.00 \\
\hline LDPE TD & 6.07 & 6.06 & 6.07 & 6.04 & 6.02 & 6.00 & 5.98 & 5.95 & 5.92 & 6.01 \\
\hline LDPE SD & 6.13 & 6.11 & 6.10 & 5.99 & 5.97 & 5.96 & 5.95 & 5.93 & 5.92 & 6.01 \\
\hline ALP TD & 6.07 & 6.09 & 6.08 & 6.05 & 6.02 & 6.00 & 5.98 & 5.95 & 5.93 & 6.02 \\
\hline ALP SD & 6.13 & 6.11 & 6.09 & 6.06 & 5.97 & 5.96 & 5.95 & 5.94 & 5.92 & 6.01 \\
\hline Mean & 6.10 & 6.08 & 6.07 & 6.02 & 5.99 & 5.97 & 5.96 & 5.94 & 5.92 & \\
\hline \multicolumn{11}{|c|}{ CD at 5\% Treatment $(T)=$ N.S Storage $(S)=$ N.S TxS $=$ N.S } \\
\hline N.S = Non-si & nnifica & & & & & & & & & \\
\hline
\end{tabular}

Table.7 Effect of different treatments on the ascorbic acid content $(\mathrm{mg} / 100 \mathrm{~g})$ of pineapple powder during storage

\begin{tabular}{|c|c|c|c|c|c|c|c|c|c|c|}
\hline \multirow[t]{2}{*}{ Treatments } & \multicolumn{10}{|c|}{ Period of storage (days) } \\
\hline & 0 & 15 & 30 & 45 & 60 & 75 & 90 & 105 & 120 & Mean \\
\hline GLASS TD & 10.23 & 10.20 & 10.01 & 9.75 & 9.09 & 8.07 & 7.98 & 7.85 & 7.73 & 8.99 \\
\hline GLASS SD & 11.37 & 11.35 & 11.10 & 9.90 & 9.25 & 8.19 & 8.19 & 8.06 & 7.95 & 9.48 \\
\hline LDPE TD & 10.23 & 10.05 & 9.15 & 8.85 & 7.54 & 6.63 & 6.53 & 6.35 & 6.24 & 7.95 \\
\hline LDPE SD & 11.37 & 11.14 & 10.22 & 9.19 & 8.01 & 6.86 & 6.60 & 6.46 & 6.36 & 8.47 \\
\hline ALP TD & 10.23 & 10.12 & 9.85 & 8.97 & 8.23 & 7.78 & 7.65 & 7.38 & 7.27 & 8.61 \\
\hline ALP SD & 11.37 & 11.23 & 10.22 & 10.17 & 8.41 & 7.89 & 7.71 & 7.50 & 7.41 & 9.10 \\
\hline Mean & 10.80 & 10.68 & 10.09 & 9.47 & 8.42 & 7.57 & 7.44 & 7.27 & 7.16 & \\
\hline
\end{tabular}

Table.8 Effect of different treatments on the water activity of pineapple powder during storage

\begin{tabular}{|c|c|c|c|c|c|c|c|c|c|c|}
\hline \multirow[t]{2}{*}{ Treatments } & \multicolumn{10}{|c|}{ Period of storage (days) } \\
\hline & $\mathbf{0}$ & 15 & 30 & 45 & 60 & 75 & 90 & 105 & 120 & Mean \\
\hline GLASS TD & 0.342 & 0.356 & 0.369 & 0.385 & 0.403 & 0.428 & 0.428 & 0.433 & 0.438 & 0.398 \\
\hline GLASS SD & 0.355 & 0.363 & 0.367 & 0.404 & 0.421 & 0.430 & 0.436 & 0.441 & 0.443 & 0.407 \\
\hline LDPE TD & 0.342 & 0.370 & 0.381 & 0.393 & 0.429 & 0.436 & 0.441 & 0.447 & 0.451 & 0.410 \\
\hline LDPE SD & 0.355 & 0.382 & 0.402 & 0.418 & 0.432 & 0.444 & 0.445 & 0.449 & 0.452 & 0.420 \\
\hline ALP TD & 0.342 & 0.366 & 0.377 & 0.389 & 0.420 & 0.425 & 0.428 & 0.430 & 0.434 & 0.401 \\
\hline ALP SD & 0.355 & 0.365 & 0.383 & 0.392 & 0.428 & 0.430 & 0.433 & 0.438 & 0.441 & 0.407 \\
\hline Mean & 0.349 & 0.367 & 0.380 & 0.397 & 0.422 & 0.432 & 0.435 & 0.440 & 0.443 & \\
\hline \multicolumn{11}{|c|}{ CD at $5 \%$ Treatment $(T)=$ N.S Storage $(S)=$ N.S TxS $=$ N.S } \\
\hline & $\begin{array}{l}=\text { Non - } \\
\text { ificant }\end{array}$ & & & & & & & & & \\
\hline
\end{tabular}


Table.9 Effect of different treatments on the solubility (\%) of pineapple powder during storage

\begin{tabular}{|l|c|c|c|c|c|c|c|c|c|c|}
\hline Treatments & \multicolumn{9}{|c|}{ Period of storage (days) } \\
& $\mathbf{0}$ & $\mathbf{1 5}$ & $\mathbf{3 0}$ & $\mathbf{4 5}$ & $\mathbf{6 0}$ & $\mathbf{7 5}$ & $\mathbf{9 0}$ & $\mathbf{1 0 5}$ & $\mathbf{1 2 0}$ & Mean \\
\hline GLASS TD & 94.1 & 92.6 & 87.7 & 86.5 & 86.4 & 86.2 & 86.1 & 85.7 & 85.5 & 87.9 \\
\hline GLASS SD & 95.1 & 95.0 & 92.2 & 91.6 & 90.2 & 89.5 & 89.3 & 89.1 & 88.9 & 91.2 \\
\hline LDPE TD & 94.1 & 91.2 & 86.0 & 85.1 & 84.7 & 84.3 & 84.1 & 83.3 & 82.5 & 86.1 \\
\hline LDPE SD & 95.1 & 93.7 & 91.8 & 89.7 & 88.7 & 88.5 & 88.4 & 88.1 & 87.7 & 90.2 \\
\hline ALP TD & 94.1 & 93.1 & 87.9 & 87.1 & 87.0 & 86.9 & 86.5 & 86.5 & 86.1 & 88.4 \\
\hline ALP SD & 95.1 & 93.6 & 90.5 & 89.1 & 88.7 & 88.6 & 88.4 & 87.9 & 87.5 & 89.9 \\
\hline Mean & 94.6 & 93.2 & 89.3 & 88.2 & 87.6 & 87.3 & 87.1 & 86.8 & 86.4 & \\
\hline CD at 5\% Treatment & $(\mathbf{T})=\mathbf{0 . 1 6}$ Storage $(\mathbf{S})=\mathbf{0 . 2 0}$ & $\mathbf{T x S}=\mathbf{0 . 4 8}$ & & & \\
\hline
\end{tabular}

Table.10 Effect of different treatments on the hygroscopicity of pineapple powder during storage

\begin{tabular}{|l|c|c|c|c|c|c|c|c|c|c|}
\hline \multirow{2}{*}{ Treatments } & \multicolumn{9}{|c|}{ Period of storage (days) } \\
\cline { 2 - 13 } & $\mathbf{0}$ & $\mathbf{1 5}$ & $\mathbf{3 0}$ & $\mathbf{4 5}$ & $\mathbf{6 0}$ & $\mathbf{7 5}$ & $\mathbf{9 0}$ & $\mathbf{1 0 5}$ & $\mathbf{1 2 0}$ & Mean \\
\hline GLASS TD & 20.92 & 19.89 & 19.61 & 19.52 & 19.49 & 19.47 & 19.45 & 19.34 & 19.21 & 19.65 \\
\hline GLASS SD & 19.13 & 19.01 & 18.85 & 18.68 & 18.69 & 18.68 & 18.66 & 18.64 & 18.62 & 18.77 \\
\hline LDPE TD & 20.92 & 19.75 & 19.70 & 19.69 & 19.68 & 19.66 & 19.64 & 19.61 & 19.60 & 19.81 \\
\hline LDPE SD & 19.13 & 19.07 & 18.95 & 18.89 & 18.75 & 18.74 & 18.72 & 18.70 & 18.69 & 18.85 \\
\hline ALP TD & 20.92 & 20.20 & 19.91 & 19.83 & 19.82 & 19.81 & 19.79 & 19.76 & 19.74 & 19.97 \\
\hline ALP SD & 19.13 & 19.07 & 18.88 & 18.86 & 18.85 & 18.74 & 18.70 & 18.68 & 18.65 & 18.84 \\
\hline Mean & 20.03 & 19.50 & 19.32 & 19.24 & 19.21 & 19.18 & 19.16 & 19.12 & 19.08 & \\
\hline CD at 5\% Treatment $\mathbf{( T )}=\mathbf{0 . 0 5 4}$ Storage $(\mathbf{S}) \mathbf{0 . 0 6 6} \mathbf{~ T x S}=\mathbf{0 . 1 6 2}$ & & & \\
\hline
\end{tabular}

Table.11 Effect of different treatments on the Total Plate Count (CFU/g) of pineapple powder during storage

\begin{tabular}{|l|c|c|c|c|c|c|c|c|c|c|}
\hline Treatments & \multicolumn{9}{|c|}{ Period of storage (days) } \\
\cline { 2 - 14 } & $\mathbf{0}$ & $\mathbf{1 5}$ & $\mathbf{3 0}$ & $\mathbf{4 5}$ & $\mathbf{6 0}$ & $\mathbf{7 5}$ & $\mathbf{9 0}$ & $\mathbf{1 0 5}$ & $\mathbf{1 2 0}$ & Mean \\
\hline GLASS TD & 33 & 110 & 133 & 167 & 203 & 230 & 253 & 280 & 317 & 192 \\
\hline GLASS SD & 50 & 107 & 140 & 210 & 233 & 257 & 283 & 313 & 340 & 215 \\
\hline LDPE TD & 33 & 140 & 183 & 243 & 267 & 297 & 330 & 390 & 413 & 255 \\
\hline LDPE SD & 50 & 157 & 200 & 250 & 267 & 287 & 350 & 403 & 430 & 266 \\
\hline ALP TD & 33 & 113 & 193 & 213 & 240 & 270 & 303 & 330 & 350 & 227 \\
\hline ALP SD & 50 & 130 & 207 & 217 & 257 & 277 & 303 & 327 & 357 & 236 \\
\hline Mean & 42 & 126 & 176 & 217 & 244 & 269 & 304 & 341 & 368 & \\
\hline CD at 5\% Treatment $\mathbf{( T )}=\mathbf{7 . 4}$ Storage $\mathbf{( S )}=\mathbf{9 . 1} \mathbf{~ T x S = 2 2 . 3}$ & & & & \\
\hline
\end{tabular}


Table.12 Effect of different treatments on the yeast and mold count (CFU/g) of pineapple powder during storage

\begin{tabular}{|c|c|c|c|c|c|c|c|c|c|c|}
\hline Treatments & \multicolumn{10}{|c|}{ Period of storage (days) } \\
\cline { 2 - 15 } & $\mathbf{0}$ & $\mathbf{1 5}$ & $\mathbf{3 0}$ & $\mathbf{4 5}$ & $\mathbf{6 0}$ & $\mathbf{7 5}$ & $\mathbf{9 0}$ & $\mathbf{1 0 5}$ & $\mathbf{1 2 0}$ & Mean \\
\hline GLASS TD & 0 & 0 & 0 & 0 & 0 & 3 & 7 & 10 & 20 & 4 \\
\hline GLASS SD & 0 & 0 & 0 & 0 & 0 & 7 & 13 & 20 & 20 & 7 \\
\hline LDPE TD & 0 & 0 & 0 & 3 & 10 & 13 & 20 & 27 & 27 & 11 \\
\hline LDPE SD & 0 & 0 & 0 & 3 & 10 & 13 & 23 & 23 & 27 & 11 \\
\hline ALP TD & 0 & 0 & 0 & 0 & 3 & 7 & 10 & 17 & 20 & 6 \\
\hline ALP SD & 0 & 0 & 0 & 0 & 7 & 7 & 10 & 17 & 23 & 7 \\
\hline Mean & 0 & 0 & 0 & 1 & 5 & 8 & 14 & 19 & 23 & \\
\hline
\end{tabular}

Table.13 Effect of different treatments on the color of pineapple powder during storage

\begin{tabular}{|c|c|c|c|c|c|c|c|c|c|c|}
\hline \multirow[t]{2}{*}{ Treatments } & \multicolumn{10}{|c|}{ Period of storage (days) } \\
\hline & $\mathbf{0}$ & 15 & 30 & 45 & 60 & 75 & 90 & 105 & 120 & Mean \\
\hline GLASS TD & 6 & 6 & 6 & 5.7 & 5.5 & 5.0 & 5.0 & 4.8 & 4.7 & 5.4 \\
\hline GLASS SD & 6 & 6 & 6 & 6.0 & 6.0 & 5.8 & 5.8 & 5.7 & 5.7 & 5.9 \\
\hline LDPE TD & 6 & 6 & 6 & 5.8 & 5.7 & 5.3 & 5.0 & 4.8 & 4.5 & 5.5 \\
\hline LDPE SD & 6 & 6 & 6 & 5.8 & 5.8 & 5.7 & 5.5 & 5.3 & 5.2 & 5.7 \\
\hline ALP TD & 6 & 6 & 6 & 5.7 & 5.3 & 5.3 & 5.2 & 4.3 & 4.0 & 5.3 \\
\hline ALP SD & 6 & 6 & 6 & 5.7 & 5.5 & 5.3 & 5.2 & 4.7 & 4.2 & 5.4 \\
\hline Mean & 6 & 6 & 6 & 5.8 & 5.6 & 5.4 & 5.3 & 4.9 & 4.7 & \\
\hline
\end{tabular}

Table.14 Effect of different treatments on the flavor of pineapple powder during storage

\begin{tabular}{|l|c|c|c|c|c|c|c|c|c|c|}
\hline \multirow{2}{*}{ Treatments } & \multicolumn{9}{|c|}{ Period of storage (days) } \\
\cline { 2 - 13 } & $\mathbf{0}$ & $\mathbf{1 5}$ & $\mathbf{3 0}$ & $\mathbf{4 5}$ & $\mathbf{6 0}$ & $\mathbf{7 5}$ & $\mathbf{9 0}$ & $\mathbf{1 0 5}$ & $\mathbf{1 2 0}$ & Mean \\
\hline GLASS TD & 6 & 6 & 6.0 & 6.0 & 5.8 & 5.7 & 5.7 & 5.5 & 5.3 & 5.8 \\
\hline GLASS SD & 6 & 6 & 6.0 & 6.0 & 6.0 & 5.8 & 5.8 & 5.5 & 5.5 & 5.9 \\
\hline LDPE TD & 6 & 6 & 5.5 & 5.3 & 5.3 & 5.2 & 4.5 & 4.3 & 4.0 & 5.1 \\
\hline LDPE SD & 6 & 6 & 5.5 & 5.3 & 5.2 & 5.0 & 5.0 & 4.3 & 4.2 & 5.2 \\
\hline ALP TD & 6 & 6 & 6.0 & 5.8 & 5.5 & 5.3 & 5.3 & 5.0 & 4.8 & 5.5 \\
\hline ALP SD & 6 & 6 & 6.0 & 5.5 & 5.5 & 5.3 & 5.3 & 5.0 & 5.0 & 5.5 \\
\hline Mean & 6 & 6 & 5.8 & 5.7 & 5.6 & 5.4 & 5.3 & 4.9 & 4.8 & \\
\hline CD at 5\% Treatment & $\mathbf{( T )}=\mathbf{0 . 1 9}$ Storage $(\mathbf{S})=\mathbf{0 . 2 3}$ TxS = N.S & & & \\
\hline
\end{tabular}

N.S = Non-significant 
Table.15 Effect of different treatments on the taste of pineapple powder during storage

\begin{tabular}{|c|c|c|c|c|c|c|c|c|c|c|}
\hline \multirow{2}{*}{ Treatments } & \multicolumn{10}{|c|}{ Period of storage (days) } \\
\cline { 2 - 13 } & $\mathbf{0}$ & $\mathbf{1 5}$ & $\mathbf{3 0}$ & $\mathbf{4 5}$ & $\mathbf{6 0}$ & $\mathbf{7 5}$ & $\mathbf{9 0}$ & $\mathbf{1 0 5}$ & $\mathbf{1 2 0}$ & Mean \\
\hline GLASS TD & 6 & 6 & 6 & 6 & 5.8 & 5.7 & 5.7 & 5.5 & 5.0 & 5.7 \\
\hline GLASS SD & 6 & 6 & 6 & 6 & 6.0 & 5.8 & 5.8 & 5.5 & 5.5 & 5.9 \\
\hline LDPE TD & 6 & 6 & 5.5 & 5.3 & 5.3 & 5.0 & 4.7 & 4.3 & 4.0 & 5.1 \\
\hline LDPE SD & 6 & 6 & 5.5 & 5.5 & 5.2 & 5.0 & 5.0 & 4.3 & 4.2 & 5.2 \\
\hline ALP TD & 6 & 6 & 6.0 & 5.8 & 5.5 & 5.5 & 5.3 & 5.0 & 4.8 & 5.6 \\
\hline ALP SD & 6 & 6 & 5.8 & 5.5 & 5.5 & 5.5 & 5.3 & 5.0 & 5.0 & 5.5 \\
\hline Mean & 6 & 6 & 5.8 & 5.7 & 5.6 & 5.4 & 5.3 & 4.9 & 4.8 & \\
\hline \multicolumn{8}{|c|}{ CD at 5\% Treatment } \\
\hline
\end{tabular}

N.S = Non-significant

Table.16 Effect of different treatments on the texture of pineapple powder during storage

\begin{tabular}{|c|c|c|c|c|c|c|c|c|c|c|}
\hline \multirow[t]{2}{*}{ Treatments } & \multicolumn{10}{|c|}{ Period of storage (days) } \\
\hline & $\mathbf{0}$ & 15 & 30 & 45 & 60 & 75 & 90 & 105 & 120 & Mean \\
\hline GLASS TD & 5.7 & 5.7 & 5.3 & 5.3 & 5.2 & 5.0 & 5.0 & 4.7 & 4.2 & 5.1 \\
\hline GLASS SD & 6.0 & 6.0 & 6.0 & 5.8 & 5.7 & 5.7 & 5.3 & 5.3 & 5.2 & 5.7 \\
\hline LDPE TD & 5.7 & 5.3 & 5.2 & 5.0 & 4.8 & 4.5 & 4.2 & 4.2 & 4.0 & 4.8 \\
\hline LDPE SD & 6.0 & 6.0 & 5.8 & 5.7 & 5.5 & 5.2 & 4.5 & 4.0 & 4.0 & 5.2 \\
\hline ALP TD & 5.7 & 5.3 & 5.2 & 5.0 & 4.8 & 4.3 & 4.3 & 4.2 & 4.0 & 4.8 \\
\hline ALP SD & 6.0 & 6.0 & 5.2 & 5.2 & 5.0 & 4.8 & 4.3 & 4.2 & 4.3 & 5.0 \\
\hline Mean & 5.8 & 5.7 & 5.4 & 5.3 & 5.2 & 4.9 & 4.6 & 4.4 & 4.3 & \\
\hline
\end{tabular}

N.S = Non-significant

Table.17 Effect of different treatments on the overall acceptability of pineapple powder during storage

\begin{tabular}{|c|c|c|c|c|c|c|c|c|c|c|}
\hline \multirow[t]{2}{*}{ Treatments } & \multicolumn{10}{|c|}{ Period of storage (days) } \\
\hline & 0 & 15 & 30 & 45 & 60 & 75 & 90 & 105 & 120 & Mean \\
\hline GLASS TD & 5.9 & 5.9 & 5.9 & 5.8 & 5.6 & 5.3 & 5.3 & 5.1 & 4.8 & 5.5 \\
\hline GLASS SD & 6.0 & 6.0 & 6.0 & 6.0 & 5.9 & 5.8 & 5.7 & 5.5 & 5.5 & 5.8 \\
\hline LDPE TD & 5.9 & 5.9 & 5.6 & 5.4 & 5.3 & 5.0 & 4.6 & 4.4 & 4.1 & 5.1 \\
\hline LDPE SD & 6.0 & 6.0 & 5.7 & 5.6 & 5.4 & 5.2 & 5.0 & 4.5 & 4.4 & 5.3 \\
\hline ALP TD & 5.9 & 5.9 & 5.8 & 5.6 & 5.3 & 5.2 & 5.1 & 4.6 & 4.4 & 5.3 \\
\hline ALP SD & 6.0 & 6.0 & 5.8 & 5.5 & 5.4 & 5.3 & 5.1 & 4.7 & 4.6 & 5.4 \\
\hline Mean & 6.0 & 5.9 & 5.8 & 5.6 & 5.5 & 5.3 & 5.1 & 4.8 & 4.6 & \\
\hline
\end{tabular}

Key for Treatments

1- GLASS TD- Tray dried pineapple powder stored in Glass bottles.

2- GLASS SD- Solar dried pineapple powder stored in Glass bottles.

3- LDPE TD- Tray dried pineapple powder stored in LDPE bags.

4- LDPE SD- Solar dried pineapple powder stored in LDPE bags.

5- $\quad$ ALP TD- Tray dried pineapple powder stored in Aluminium laminated pouches.

ALP SD- Solar dried pineapple powder stored in Aluminium laminated pouches 
The osmotic solutions investigated significantly influenced the taste and texture profile of the dehydrated fruit and affected their sensory acceptability but the changes depended on the fruit species and on the drying method used. Karel, 1975 reported that osmotic dehydration minimizes the heat damage to food tissue, colour, flavor and fewer discolourations of fruits by enzymatic oxidative browning. Bolin, 1983 reported that the advantages of osmotic dehydration include; increasing retention of natural volatile flavours. Flink (1975) reported that dried fruit product flavor quality depended primarily on the initial solids content. If the solids concentration was increased, the retention of volatiles was greatly improved. An osmotic treatment of fruits in a 60 to 65 ${ }^{\circ}$ Brix sugar solution was used in order to increase the initial solids content prior to freeze drying components during further dehydration, improving textural quality and reducing energy needs.

From the results obtained in the present study, it can be concluded that the pineapple powder produced was of very good quality. Solar dried pineapple powder was slightly better than tray dried pineapple powder especially in terms of sensory quality. Quality of solar dried products differs from place to place. Solar drying during the hottest period of the year and temperature optimization for tray drying ensured the pineapple powder produced was of very good quality.

Osmotic dehydration as a pretreatment step for further dehydration had a significant impact on the quality of pineapple powder. The different packaging materials were able to keep the desired pineapple powder properties throughout the storage period. Glass was the best material for storage of pineapple powder followed by aluminium laminated pouches. However for commercial purposes aluminium laminated pouches and
LDPE bags may be used as they are light, flexible and cheaper.

The pineapple powder produced had very good shelf life and still had acceptable quality parameters at the end of the storage period hence offering great potential for use as an ingredient in different kinds of food and beverages.

\section{References}

A.O.A.C. 1999. Official Methods of Analysis of AOAC International. 15th edn. Association of Official Analytical Chemists, Washington D.C USA.

Alvarez, P.I. and C. Shene. 1994. Experimental determination of volumetric heat transfer coefficient in a rotary dryer. Drying Technology, 12(7): 1605-1627.

Barbosa-Canovas and Mercado Vega. 1996. Dehydration of foods. Chapman \& Hall, New York.

Barbosa-Canovas Gustavo V., Ortega-Rivas, E, Pablo Juliano and Hong Yan. 2005. Food powders, physical properties, processing and functionality. Chapman \& Hall, New York, pp: 19-40, 55-57, 334-335.

Bartolomé, P. Rupérez and Fúster. C. 1995. Pineapple Fruit: Morphological Characteristics, Chemical Composition and Sensory Analysis of Red Spanish and Smooth Cayenne Cultivars. Journal of Food Chemistry, 53: 75-79.

Bolin, H. R. 1983. Effect of osmotic agents and concentration on fruit quality. Journal of Food Science, 48: 202-212.

Cano-Chauca, M., Stringheta, P.C., Ramos, A.M. and Cal-Vidal, J. 2005. Effect of the carriers on the microstructure of mango powder obtained by spray drying and its functional characterization. Innovative Food Science and Emerging Technologies 6: 420-428.

Chegini, R.G. and Ghobadian, B. 2005. Effect of spray-drying conditions on physical properties of orange juice powder. Drying Technology 23: 657-668.

Dattatreya M. Kadam, Robin A. Wilson and Varinder Kaur. 2012. Physicochemical and microbial quality evaluation of foam-mat- 
dried pineapple powder. International Journal of Food Science \& Technology, 47:1654-1659.

DiPersio, P.A., Kendall, P.A. and Sofos, J.N. 2006. Sensory evaluation of home dried fruit prepared using treatments that enhance destruction of pathogenic bacteria. Journal of Food Quality, 29:47-64.

Flink, J. M. 1975. Process conditions for improved flavor quality of freeze dried foods. Journal of Agricultural Food Chemistry, 23: 1019 - 1023, 26.

Hemalatha. $\mathrm{R}$ and S. Anbuselvi. 2013. Physicochemical constituents of pineapple pulp and waste. Department of Industrial Biotechnology, Bharath University, Chennai Journal of Chemical and Pharmaceutical Research, 5(2): 240-242

Joy P.P and Abraham Minu. 2013. Fruits, benefits, processing, preservation and pineapple recipes. Pineapple Research Station, Kerala Agricultural University.

Juliana Nascimento da Costa, Raimundo Wilane de Figueiredo and Paulo Henrique. 2013. Study of the stability of passion fruit (Passiflora edullis $f$. flavicarpa) powder from organic farming. Ciências Agrárias, Londrina, 34:705-716.

Karel, M. 1975. Osmotic drying, Principles of Food Science: Part II, O.R. Fennema (ed.) Marcel Dekker, New York, NY.

Karim, O.R. 2005. Effect of pre-treatment on drying kinetics and quality attributes of air dehydrated pineapple slices. $\mathrm{PhD}$ thesis, University of Agriculture, Abeokouta, Ogun State, Nigeria.

Konopacka. D, Jesionkowska. K, R.Klewicki and C. Bonazzi. 2009. The effect of different osmotic agents on the sensory perception of osmo-treated dried fruit. Journal of Horticultural Science \& Biotechnology ISAFRUIT Special Issue. Pp. 80-84.
Masters K. 1976. Spray drying Handbook. John Wiley \& sons, New York. Pineapple India, 2012. C-26/3, Half Nagarjan, Dimapur, Nagaland 797112.

Pedro MAM., Telis-Romero, $\mathrm{J}$ and Telis VRN. 2010. Effect of drying method on the absorbtion isotherms and isostericheat of passion fruit pulp powder. Food Science and Technology (Campinas). 30(4):993-1000.

Pineapple India, 2012. C-26/3, Half Nagarjan, Dimapur, Nagaland 797112.

Ranganna, S. 2003. Hand book of analysis and quality control for fruit and vegetable products. Tata McGraw-Hill Publishing Co. Ltd., New Delhi.

Sharma, K.D, Alkesh and B. B Lal Kaushal. 2003. Quality of Apple powder as Affected by Packaging Materials during Storage. Journal of Scientific and Industrial research, 62: 609-615.

Shrestha Ashok. 2007. Glass Transition behaviour of spray dried orange juice. University of Western Sydney. International Journal of Food Properties, 10: 661- 673.

Suhaimi Mohd, O. Abd Malik, S. Asmui and O. Ahmad Shokri. 2010. Production and properties of spray dried pineapple juice. ISHS Acta Horticulture 902: VII International Pineapple Symposium.

Swain S, Samuel DVK, Kar A. 2013. Effect of Packaging Materials on Quality Characteristics of Osmotically Pretreated Microwave Assisted Dried Sweet Pepper (Capsicum annum L.). Journal of Food Processing Technology 4: 264.

Toledo R.T., 1991. Fundamentals of Food Process Engineering, second edition. Chapman \& Hall New York.

Zakaria Rahari. 2005. Development of pineapple core powder. Malaysian Agricultural Research and Development Institute (MARDI), Johor Bahru 802000, Malaysia.

\section{How to cite this article:}

Sango Lule Victor, Mukesh Kumar Garg and Kanika Pawar. 2019. Effect of Different Drying Techniques on the Quality Attributes of Pineapple Powder. Int.J.Curr.Microbiol.App.Sci. 8(02): 324-341. doi: https://doi.org/10.20546/ijcmas.2019.802.038 